\title{
Prediksi Energi Listrik Kincir Angin Berdasarkan Data Kecepatan Angin Menggunakan LSTM
}

\author{
Muhammad Qubaisy Andiyantama, Iffah Zahira, Ade Irawan
}

Universitas Pertamina, Jakarta Selatan, Indonesia

\section{ARTICLE INFORMATION}

Received: September $27^{\text {th }}, 2020$

Revised: March 23 ${ }^{\text {rd }}, 2021$

Available online: March $31^{\text {st }}, 2021$

\section{KEYWORDS}

Energy, Fossil, Renewable, Wind Turbines, Area, Stability

\section{CORRESPONDENCE}

Phone: +62 87711247565

E-mail: qubaisya@gmail.com

\section{A B S T R A C T}

Energy has an important role meeting people's life needs. Today, the most energy is produced from fossil energy, which always leads to damage both in the process of taking raw materials until their use and fossil energy becomes an increasingly thinning amount. The main solution to solve those problems is using renewable energy. The example that can be taken from renewable energy that successfully used is wind turbines. However, wind turbines in Indonesia are relatively new and newly developed in 2018 and still have a lot of problems in its implementation and usage. One of the problems is the electricity that is generated from wind turbines is unstable that is caused by instability of wind speed in the area of wind turbines placed. In this study, we used the data of wind speed from one of the areas and predicted the wind turbine using LSTM. Therefore, we can get information about the stability of the wind speed in that area and how much energy could be generated. Thus, wind turbines can be built in the right area with a system that suits it needs. That way, the utilization will be more effective and efficient.

\section{PENDAHULUAN}

\section{Latar Belakang}

Kebutuhan manusia terhadap energi semakin meningkat dan energi fosil yang selama ini digunakan semakin menipis. Di Indonesia sendiri, energi fosil diperkirakan habis pada tahun 2025 [11]. Berbagai cara dilakukan untuk terus membuat energi tetap tersedia. Akan tetapi, akibat penggunaan energi fosil yang terus-menerus ini, bumi terkena imbasnya. Udara menjadi kotor, jarak pandang menipis, dan global warming terus meningkat. Karena itulah seperti yang kita tahu, banyak orang yang berinovasi menciptakan alat yang dapat membantu manusia beralih dari penggunaan energi fosil menjadi energi terbarukan atau setidaknya mengurangi penggunaan dari energi fosil itu sendiri.

Indonesia termasuk salah satu negara yang tertinggal dalam pemanfaatan energi terbarukan yang mana masih jauh dari target [8]. Tantangan yang dihadapi untuk mengembangkan energi terbarukan tidaklah mudah. Salah satu energi terbarukan yang memungkinkan untuk diimplementasikan termasuk di Indonesia adalah energi angin. Angin dihasilkan oleh udara yang berpindah dan udara dapat ditemukan di seluruh penjuru bumi. Akan tetapi, tidak seluruhnya dapat dimanfaatkan secara maksimal, hal tersebut bergantung pada kecepatan angin yang ada pada tempat tersebut [7]. Oleh karena itu, penentuan wilayah yang tepat sebagai penempatan kincir angin menjadi salah satu hal yang penting. Kita perlu memastikan potensi angin di wilayah tersebut, sehingga kita dapat memperkirakan seberapa besar energi yang dapat dihasilkan serta bagaimana sistem kincir angin yang harus dibangun jika kincir angin dipasang di wilayah tersebut.

Indonesia sendiri merupakan wilayah yang memiliki kecepatan angin yang cenderung fluktuatif. PLTB yang didirikan pertama kali di Indonesia pada tahun 2018, di Sidrap, Sulawesi Selatan, atau yang biasa disebut PLTB Sidrap, diperkirakan mampu mengalirkan listrik ke lebih dari 70000 pelanggan dengan daya 900 VA [3][4][8]. Namun, pada kenyataannya, masyarakat masih mengeluhkan jika listrik yang didapat tidak stabil dan dapat memicu adanya kerusakan alat elektronik. Hal tersebut membuktikan, sistem kincir angin yang digunakan belum sesuai dengan wilayah terkait, karena belum mampu menghadapi ketidakstabilan kecepatan angin yang datang [17].

Untuk menghadapi beberapa tantangan tersebut, kita membutuhkan sebuah teknologi yang dapat membantu pembangunan PLTB agar menjadi lebih baik. Teknologi yang dimaksud adalah teknologi yang dapat membantu merekomendasikan wilayah serta sistem kincir angin yang harus dibangun. Untuk itu, kami mengusulkan solusi dengan men-train data kecepatan angin secara univariate dengan model LSTM (Long Short-Term Memory), sehingga menghasilkan prediksi kecepatan angin dan energi listrik yang dapat dihasilkan kincir angin. Terdapat karya tulis pada Jurnal Teknik ITS yang terkait dengan solusi yang kami usulkan, dengan judul "Prediksi Kecepatan Angin Jangka Pendek Menggunakan Metode Fuzzy Linear Regression Untuk Mendapatkan Masukan Pada Kontroler 
Turbin Angin". Dalam karya tersebut, metode yang digunakan untuk men-train data adalah multivariate, karena data yang digunakan dibagi oleh fitur-fitur yang digunakan sebagai variabel masukan serta variabel keluaran sebagai targetnya yaitu kecepatan angin. Sedangkan model yang digunakan adalah model fuzzy linear regression [16].

Penggunaan LSTM pada solusi yang kami usulkan, diharapkan memiliki hasil yang lebih baik dibanding model fuzzy linear regression, karena LSTM memiliki kemampuan mengingat hal-hal yang penting dan melupakan yang tidak penting sehingga prediksi yang dihasilkan telah dipertimbangkan dari data di masa lalu.

\section{Manfaat}

Manfaat yang akan didapatkan ketika mengimplementasikan sistem ini adalah:

1. Mengetahui suatu wilayah merupakan pilihan yang tepat untuk memasang kincir angin agar menghasilkan energi yang stabil.

2. Mengetahui jenis dan sistem kincir angin yang tepat untuk dipasang di wilayah tertentu.

3. Mengetahui blade radius kincir angin yang cocok berdasarkan jumlah energi yang dibutuhkan.

4. Mengetahui potensi energi yang dapat dihasilkan kincir angin di suatu wilayah.

\section{MATERIAL DAN METODOLOGI \\ Dasar Teori}

Kincir Angin

Kincir angin konvensional yang biasa digunakan dapat dibagi menjadi dua, yaitu kincir angin sumbu horizontal dan kincir angin sumbu vertikal. Kincir angin yang bersumbu horizontal dapat menangkap kecepatan angin lebih baik sedangkan kincir angin bersumbu vertikal lebih baik dalam menangkap angin dari segala arah hanya saja kecepatan yang didapat tidak lebih baik. Oleh sebab itu, pada perancangan ini kami lebih mengutamakan penggunaan kincir angin horizontal, karena kecepatan angin yang besar dapat menghasilkan energi yang besar pula. Selain itu, kincir angin horizontal juga tetap dapat menangkap angin dengan arah berbeda, meskipun membutuhkan waktu yang lebih lama dibanding kincir angin vertikal [9].

Perhitungan yang digunakan pada perancangan ini, untuk menentukan power yang dihasilkan kincir angin yaitu:

$P=\pi / 2 \times r^{2} \times v^{3} \times \rho \times \eta$

$\mathrm{p}=$ power $\left(\right.$ watt atau $\left.\mathrm{kg} \times \mathrm{m}^{2} / \mathrm{s}^{3}\right)$

$\mathrm{r}=\operatorname{radius}(\mathrm{m})$

$\mathrm{v}=$ kecepatan angin $(\mathrm{m} / \mathrm{s})$

$\rho=$ kerapatan udara $\left(\mathrm{kg} / \mathrm{m}^{3}\right)$

$\eta=$ faktor efisiensi $(\%)$

Terdapat berbagai macam persamaan untuk menentukan power yang dihasilkan kincir angin. Persamaan di atas dipilih untuk digunakan pada perancangan ini, dikarenakan mudah untuk dipahami dan telah banyak digunakan [14][15]. Perlu diketahui, penggunaan persamaan manapun tidak masalah asalkan memiliki data kecepatan angin yang sesuai dan sisanya hanya perlu disesuaikan berdasarkan kebutuhan.

Menurut Albert Betz, tidak ada kincir angin yang dapat menghasilkan efisiensi energi melebihi 59,3\% yang biasa disebut dengan betz limit law. Karena hal tersebut, nilai faktor efisiensi harus kurang dari ketentuan betz limit [5]. Berdasarkan penelitian yang dilakukan, airfoil system atau sistem yang bekerja layaknya kincir angin horizontal bekerja, efisiensi yang dapat dihasilkan adalah antara 50 dan $53 \%$ dan $44-45 \%$ untuk VAWT system atau sistem yang bekerja pada kincir angin vertikal [1]. Kerapatan udara pada permukaan air adalah $1,2 \mathrm{~kg} / \mathrm{m}^{3}$ sesuai dengan standar suhu dan tekanan [6]. Semakin tinggi dari permukaan air atau semakin dingin suatu tempat, maka kerapatan udara juga dapat berubah. Sedangkan radius adalah panjang dari rotor blade yang ada pada kincir angin. Kecepatan angin dapat diukur dengan berbagai alat yang sudah ada saat ini seperti Anemometer, atau jenis alat pengukur angin lainnya [2]. Kecepatan angin dapat berbeda-beda bergantung dengan perbedaan tekanan udara, asal atau tujuan angin, ataupun resistensi medan yang dilaluinya [12].

\section{LSTM}

Long Short-Term Memory networks atau LSTM adalah salah satu jenis arsitektur RNN yang dikenalkan pertama kali oleh Hochreiter \& Schmidhuber pada tahun 1997[13]. Hal yang membedakan LSTM dengan RNN biasa adalah LSTM mampu mempelajari informasi mana yang harus dibuang dan informasi mana yang harus tetap disimpan dalam memory cell.

Gambar 2.1. Neuron pada LSTM

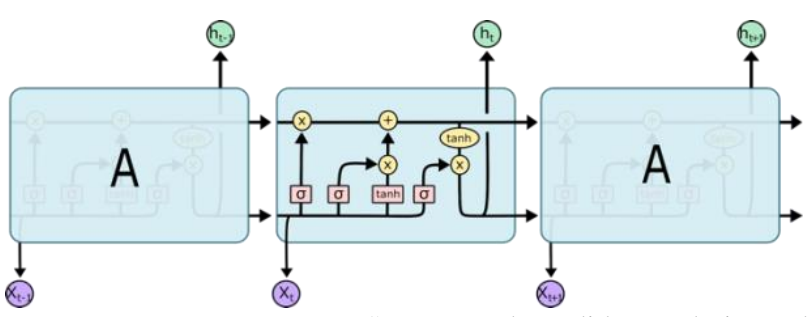

Kemampuan LSTM tersebut didapat dari struktur neuron LSTM yang berbeda dengan neuron RNN biasa. Setiap neuron LSTM memiliki memory cell dan gate units. Memory cell pada LSTM berfungsi untuk menyimpan informasi. Sedangkan gate units berfungsi untuk mengatur informasi. Memory cell pada LSTM menyimpan informasi yang nantinya dapat diikutkan pada neuron selanjutnya dan gate units mengatur bagian-bagian dari memory cell yang harus diikutkan dan dibuang. Terdapat empat proses yang umum pada setiap neuron. Berikut adalah cara kerja dari setiap proses di neuron LSTM.

Proses yang pertama adalah menyaring informasi yang harus dibuang. Forget gate yang merupakan fungsi sigmoid dan dilambangkan dengan $\boldsymbol{f}_{\boldsymbol{t}}$, akan membaca nilai $\boldsymbol{h}_{\boldsymbol{t}-\boldsymbol{1}}$ dan $\boldsymbol{x}_{\boldsymbol{t}}$, yang menghasilkan nilai 0 atau 1 untuk setiap elemen dalam $\boldsymbol{C}_{\boldsymbol{t}}$ ${ }_{1}[10][13]$. Nilai 0 menunjukkan bahwa elemen (informasi) harus dibuang. Sebaliknya, nilai 1 menunjukkan bahwa elemen (informasi) harus tetap disimpan.

Gambar 2.2.Proses Pertama LSTM

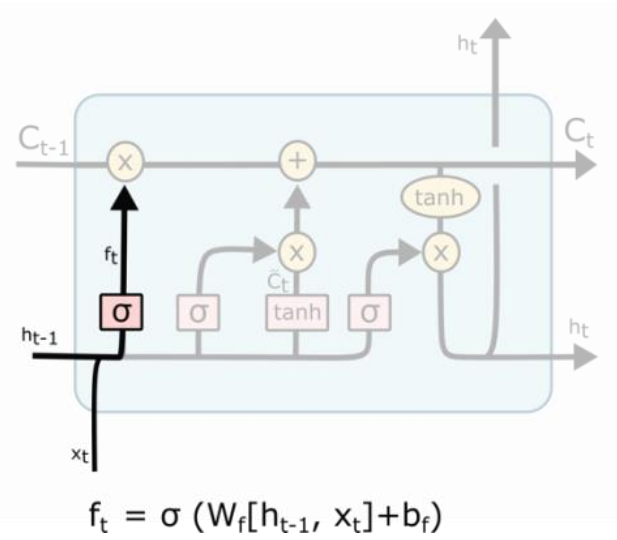


Pada proses selanjutnya, terdapat input gate dan tanh. Input gate juga merupakan fungsi sigmoid. Input gate atau It menentukan informasi mana yang akan diperbarui dan fungsi tanh akan membuat vektor baru yaitu $\tilde{\boldsymbol{C}}_{t}[10][13]$.

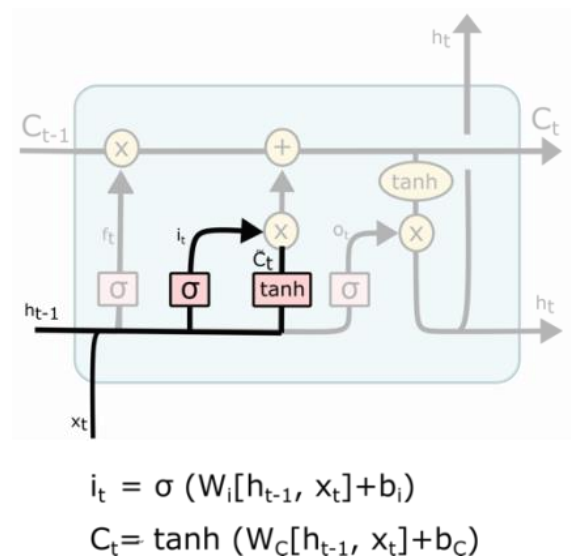

Gambar 2.3. Proses Kedua LSTM

Proses selanjutnya adalah memperbarui memory cell dari $\boldsymbol{C}_{\boldsymbol{t}-\boldsymbol{I}}$ menjadi $\boldsymbol{C}_{\boldsymbol{t}}$. Untuk mendapatkan $\mathrm{Ct}, \boldsymbol{f}_{\boldsymbol{t}}$ harus dikalikan dengan $\boldsymbol{C}_{\boldsymbol{t}-\boldsymbol{I}}$, dan $\boldsymbol{i}_{t}$ harus dikalikan dengan $\tilde{\boldsymbol{C}}_{\boldsymbol{t}}$. Kemudian, hasil dari kedua operasi perkalian tersebut dijumlahkan[10][13].

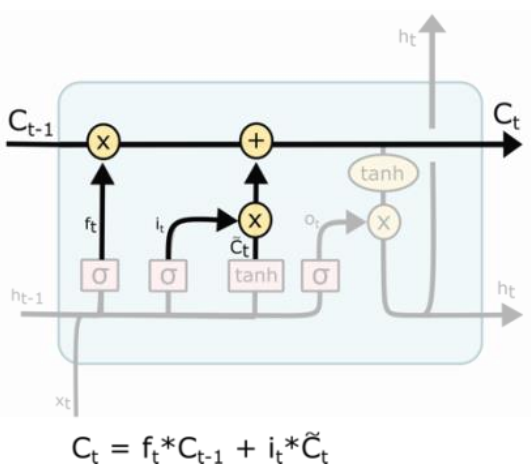

Gambar 2.4. Proses Ketiga LSTM

Proses terakhir adalah menentukan output. Pada proses ini, fungsi sigmoid (output gate, ot) akan dijalankan untuk mendapatkan bagian-bagian dari memory cell yang akan menjadi output dan tanh akan memproses $\boldsymbol{C}_{\boldsymbol{t}}$ untuk mendapat nilai antara 1 dan -1. Sehingga, untuk menentukan output, hasil dari output gate dan tanh dikalikan [10][13].

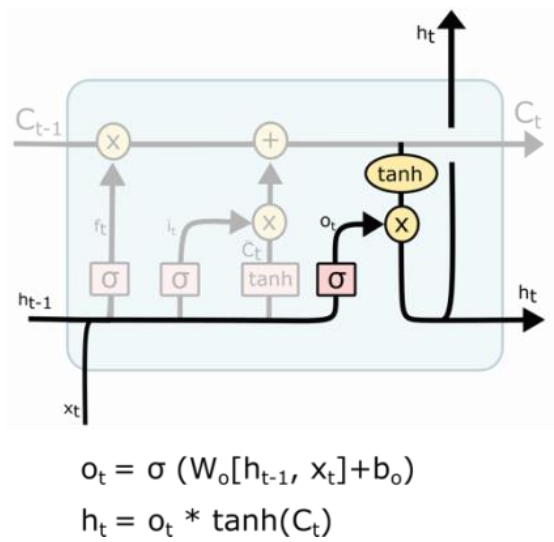

\section{Perancangan}

Dataset

Dataset yang digunakan pada perancangan ini adalah data appliances energy prediction yang didapat dari https://archive.ics.uci.edu/ milik University of California. Data tersebut dikumpulkan di Chievres weather station, kota Chievres, Belgia. Data yang digunakan merupakan data 4,5 bulan pertama tahun 2016 dengan interval waktu setiap data adalah 10 menit. Alasan memilih untuk menggunakan data ini, karena data ini memiliki nilai yang continues dan jarak time series-nya adalah setiap 10 menit. Jarak time series semakin kecil semakin baik. Dengan time series yang kecil, data yang digunakan akan semakin banyak, hal tersebut memudahkan LSTM dalam mengingat, sehingga hasil yang didapatkan menjadi lebih presisi. Dataset ini memiliki 29 atribut, namun pada perancangan ini, hanya dua atribut saja yang dibutuhkan, sedangkan atribut lainnya berhubungan dengan penggunaan appliances dan tidak berhubungan dengan perancangan ini. Format dataset yang digunakan adalah csv. Pada tabel di bawah ini terdapat penjelasan untuk atribut dari dataset yang digunakan.

Table 2.1. Atribut Data

\begin{tabular}{|l|l|l|}
\hline Atribut & Format & Deskripsi \\
\hline Date & object & $\begin{array}{l}\text { Waktu rekaman } \\
\text { dilakukan }\end{array}$ \\
\hline Windspeed & float & $\begin{array}{l}\text { Kecepatan angin } \\
\text { pada waktu tertentu }\end{array}$ \\
\hline
\end{tabular}

\section{Penggunaan Dataset}

Seperti yang sudah dijelaskan sebelumnya, data yang akan digunakan adalah date dan wind speed. Sebelum dataset mulai digunakan, kami memastikan terlebih dahulu data kecepatan angin yang akan digunakan sudah kontinu, dengan melihat describe-nya seperti berikut:

\begin{tabular}{|lr|}
\hline count & 19735.000000 \\
mean & 4.039752 \\
std & 2.451221 \\
min & 0.000000 \\
$25 \%$ & 2.000000 \\
$50 \%$ & 3.666667 \\
$75 \%$ & 5.500000 \\
max & 14.000000 \\
Name: Windspeed, dtype: float64
\end{tabular}

Gambar 2.6. Describe data atribut Windspeed 
Dari gambar di atas, dapat dilihat persebaran data cukup luas dan besar. Jika diplotkan, kecepatan angin per 10 menit memiliki jumlah dan persebaran yang berbeda-beda, seperti yang dapat dilihat pada gambar 2.7 dibawah ini.

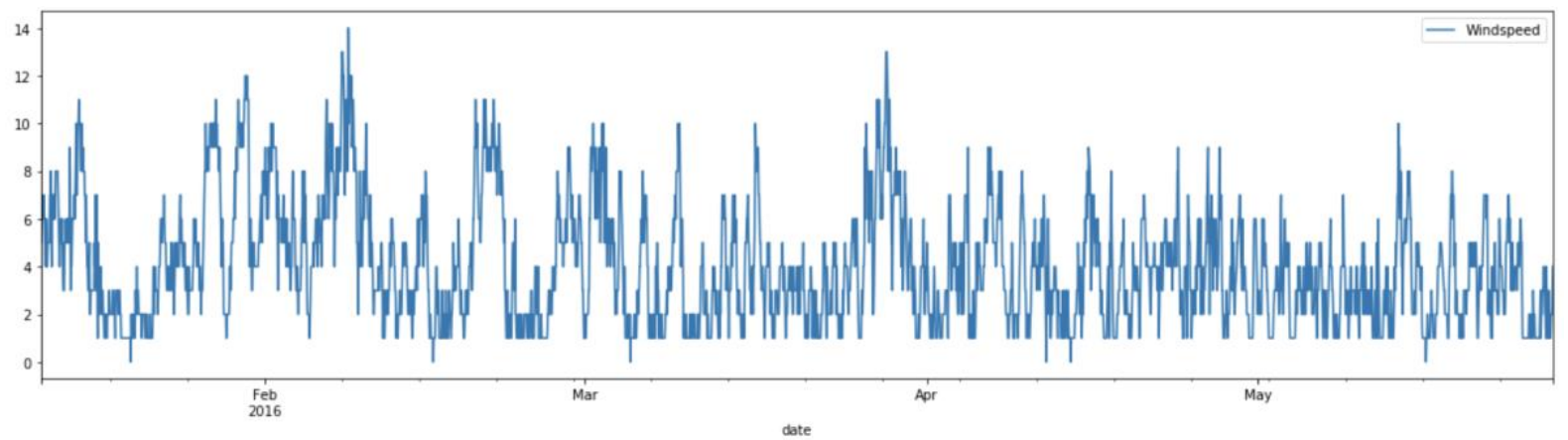

Gambar 2.7. Time series atribut Windspeed

Dataset tersebut memiliki 19736 baris data dan 29 kolom. Hal pertama yang kami lakukan setelah memastikan dataset kontinu adalah mengubah atribut date yang berformat object menjadi datetime, yang berfungsi untuk memudahkan penggunaan data time series. Setelah itu, kami memastikan time series dari atribut Windspeed tersebut stationary atau tidak. Jika dilihat sekilas pada gambar 2.7, value Windspeed terlihat sudah stationary dan tidak perlu diatur lagi. Akan tetapi, mean dan variansi data tersebut tidak begitu konstan.

Pada perancangan ini, kami melakukan percobaan terhadap dua jenis data yang berbeda. Pada percobaan pertama, dilakukan perubahan data menjadi stationary dan percobaan kedua tanpa mengubah data menjadi stationary. Hal tersebut dilakukan karena dari data yang dilihat pada gambar 2.7, data terlihat tidak memiliki tren tetapi tidak dapat dibilang konstan juga, sehingga kami melakukan dua percobaan untuk menentukan mana yang terbaik dilakukan. Selanjutnya, data time series yang sudah stationary akan dijadikan supervised karena LSTM di keras mengharuskan data dibagi menjadi input(X) dan output(y) komponen. Untuk menyelesaikan masalah tersebut pada time series, data dari satu langkah waktu sebelumnya sebagai input dan data dari waktu yang sekarang sebagai output. Dengan bantuan fungsi shift() dari pandas maka akan dapat memasukkan value dengan 1 pergeseran. Kemudian, kedua series tersebut digabungkan menjadi dataframe dan siap digunakan sebagai supervised learning. Setelah itu, data akan dibagi menjadi dua yaitu untuk data test sebanyak 109 data terakhir dan sisanya digunakan untuk train. Setelah sudah supervised learning dan dibagi menjadi train dan test, kedua pembagian data test dan train harus di scale sesuai dengan activation yang digunakan pada LSTM. Activation default untuk LSTM adalah hyperbolic tangent (tanh) yang mana output value-nya di antara -1 dan 1 . Data dapat diubah pada jarak antara -1 dan 1 dengan menggunakan kelas MinMaxScaler dari sklearn.

Seperti yang dapat dilihat pada gambar blok diagram 2.8 , layer yang dibuat terdapat empat termasuk input layer di dalamnya. Untuk meng-input layer pada LSTM di keras, dibutuhkan matrik tiga dimensi sebagai [samples, time steps, features]. Dari input yang dimasukkan ke LSTM dengan jumlah neuron yang dimasukkan adalah 50. Setelah itu akan dilakukan dropout untuk menghindari overfitting. Lalu output layer yang membuat prediksi single value.

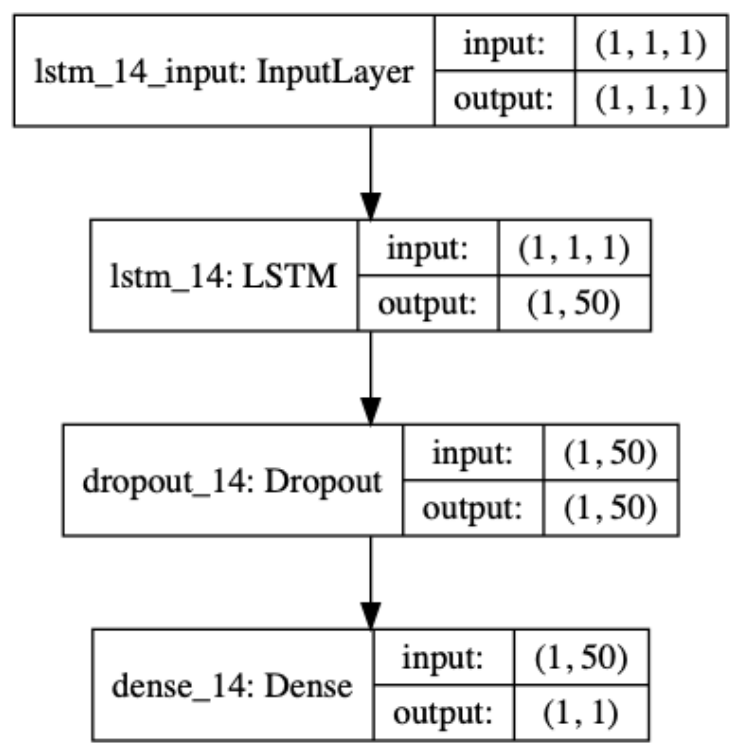

Gambar 2.8. Blok diagram

\section{HASIL DAN PEMBAHASAN}

Pada percobaan untuk menentukan data harus diubah menjadi stationary atau tidak dapat kami ambil keputusan bahwa data perlu untuk diubah menjadi stationary karena kami telah melakukan pengujian dengan epochs hanya 50 untuk melakukan tes hasil saja. Setelah dilakukan tes tersebut didapatkan bahwa RMSE setelah diubah menjadi stationary adalah 0.105 sedangkan jika tidak diubah adalah 0.157 sehingga keputusan terbaik adalah tetap merubahnya menjadi stationary.

Setelah menentukan stationary, maka dilakukan training data yang benar. Training dilakukan dengan epochs sebanyak 1500 kali yang memakan waktu lebih dari 20 jam. Pada saat training, dapat dilihat pada gambar 3.1, loss yang terjadi tampak mengecil hingga akhirnya konstan, dibuktikan dengan perubahan yang naik turun, tetapi angkanya hanya berkisar pada 0.009 hingga 0.006 , angka tersebut terbilang kecil dengan perbedaan yang tidak jauh karena dua 0 di belakang koma merupakan angka yang kecil. 


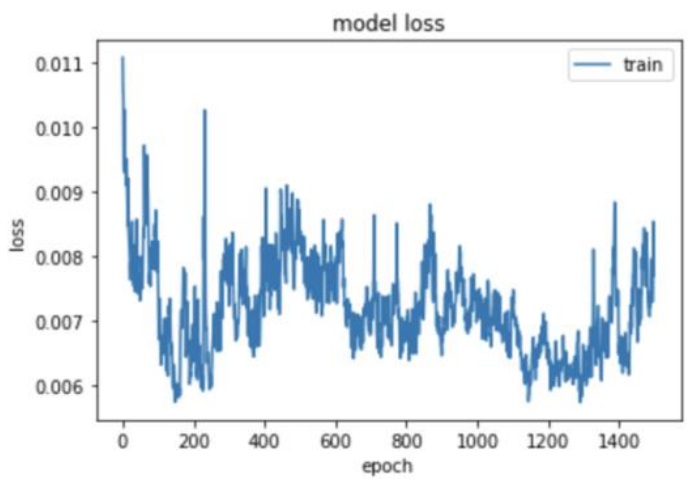

Gambar 3.1. Grafik loss

Setelah forecast dilakukan, scale dan differences akan dikembalikan nilainya. Dapat dilihat pada gambar 3.1, bahwa hasil yang didapat cukup memuaskan dengan loss sekecil itu dan nilai RMSE (Root Mean Square Error) yang didapat adalah 0.095. Pada perancangan yang sudah ada, seperti yang disinggung pada latar belakang, tertulis data yang digunakan pada perancangannya terdapat dua jenis data yaitu data dengan reduksi dan data tanpa reduksi yang mana tanpa reduksi bermaksud pengambilan data dari wilayah dataran rata dan dengan reduksi bermaksud diambil dari wilayah perumahan dan terdapat hal yang bisa mengurangi kecepatan angin seperti pohon[16]. Rata-rata kesalahan (error) dari prediksi yang dilakukannya pada data tanpa reduksi adalah sebesar 0.08 dengan titik nilai kesalahan terendah sebesar 0.0013 dan tertinggi sebesar 1.14 , sedangkan rata-rata kesalahan yang didapat dari penggunaan data dengan reduksi adalah 2.06 dengan kesalahan terbesar berada pada nilai 7.78 dan terkecil 0.048[16].

Jika dibandingkan dengan kesalahan atau loss yang didapatkan dengan rancangan yang kami buat, dapat dilihat pada gambar 3.1 bahwa kesalahan yang didapatkan pada nilai terbesar 0.011 dan nilai terkecil yang mana jika di cross-check dapat dilihat nilai terkecil adalah 0.0057 dan dibulatkan oleh fungsi $\min ()$ menjadi 0.006 , dengan nilai rata-rata 0.007. Dapat disimpulkan bahwa rancangan yang kami buat lebih baik karena dengan nilai rata-rata yang lebih kecil dan bahkan nilai rataratanya mendekati nilai terkecil dari kesalahan. Selain itu, jika dilihat lebih detailnya lagi, kesalahan terkecil yang dilakukan oleh rancangan yang sudah ada tersebut memiliki nilai terkecil 0.0013 pada titik ke-605 yang berarti titik terkecil tersebut hanya terjadi sekali saja, dan jika kembali dilihat pada gambar 3.1, rancangan yang kami buat memiliki kesalahan yang konstan yang berarti titik terkecil dan terbesarnya terjadi pada rentan yang sama sehingga rata-ratanya pun akan tetap sama. Pada perancangan yang sudah ada, dengan kedua data yang digunakan, nilai kesalahan terkecil cenderung terjadi pada data tanpa reduksi. Jika kami mengikuti konsep dari perancangan tersebut, data yang kami gunakan adalah data dengan reduksi karena diambil dari salah satu station dan hasil yang didapat pun hasil yang baik dan kesalahan yang stabil yang berarti rancangan yang kami buat dapat digunakan untuk jenis angin apapun.

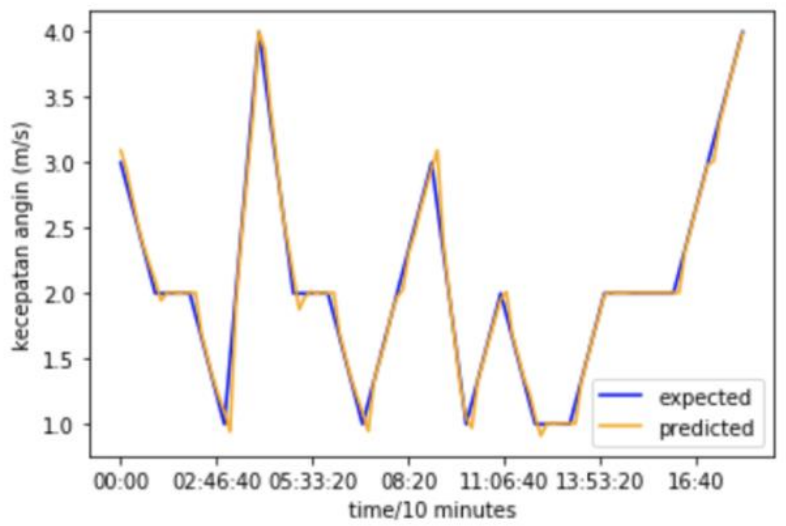

Gambar 3.2. Grafik ekspektasi vs prediksi

Pada perancangan yang dilakukan, kami tidak mentrain model berdasarkan power-nya, tetapi berdasarkan kecepatan anginnya. Hal tersebut disebabkan oleh pengumpulan data atau ketersediaan data dari kecepatan angin lebih mudah didapat karena dengan begitu hasil prediksi akan lebih mudah didapat dengan atribut data dan upaya yang minimal. Terlebih lagi, hasilnya dapat dimanfaatkan secara luas sesuai kebutuhan. Mengingat salah satu manfaat yang bisa didapat dari perancangan ini adalah penentuan wilayah yang tepat untuk pemasangan kincir angin beserta sistemnya. Maka dari itu, jika data yang digunakan power-nya maka kincir angin harus dipasang terlebih dahulu untuk mendapatkan datanya. Hal tersebut tidak efisien jika dibandingkan dengan data kecepatan angin. Ketika data kecepatan angin sudah di-train kami pun mengkonversi hasil prediksinya menjadi power dengan persamaan yang sudah dijelaskan sebelumnya. Berikut adalah grafik hasil perhitungan power yang dihasilkan berdasarkan kecepatan angin.

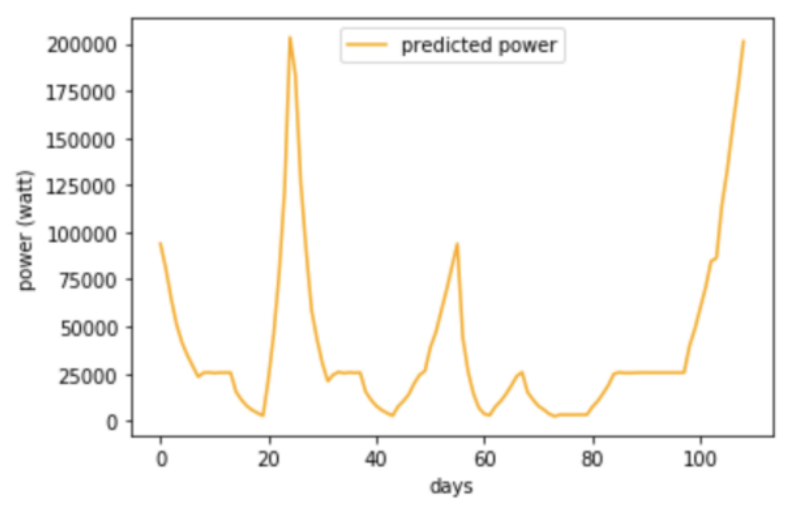

Total power $=4177448.821680647$ watt

Gambar 3.3. Grafik power yang dihasilkan

Hasil tersebut bisa didapatkan karena data yang digunakan kontinu dengan kerenggangan time series data yang cukup kecil yaitu 10 menit. Sehingga, untuk memprediksi dalam sehari kedepan, data sudah cukup baik. 


\section{KESIMPULAN DAN SARAN}

Kesimpulan yang didapat dari hasil perancangan ini adalah LSTM dapat memprediksi kecepatan angin di suatu wilayah untuk satu hari kedepan, dengan data time series 4.5 bulan dan jarak antar data 10 menit saja. Pemilihan data sangat penting untuk menunjang kesuksesan dalam melakukan prediksi ini, itulah sebabnya mengapa data harus di cek terlebih dahulu apakah data kontinu atau tidak. Keputusan untuk mengubah data menjadi stationary atau tidak juga dapat menghasilkan tingkat ketepatan prediksi. Pemberian nilai neuron pada LSTM juga dapat mempengaruhi hasil. Dari percobaan yang dilakukan, penggunaan neuron dapat disesuaikan dengan banyaknya data. Sebelumnya, neuron yang kami gunakan hanya 4 dan sudah menghasilkan prediksi yang baik, tetapi ketika kami ubah neuron menjadi 50 hasil prediksi yang didapatkan jauh lebih baik lagi.

Dengan dikembangkannya model untuk memprediksi kecepatan angin ini, dengan dikonversikan menjadi power akan sangat berguna untuk dapat menentukan suatu wilayah tersebut adalah wilayah yang tepat atau tidak untuk penempatan kincir angin dan berapa peluang energi yang mungkin dihasilkan. Prediksi seperti ini sangat berguna jika seseorang yang memiliki rumah dengan banyak angin di wilayahnya, untuk menentukan pilihan. Bahkan jika pemerintah atau instansi lain ingin membangun PLTB di suatu wilayah, rancangan ini dapat membantu merekomendasikan wilayah dan sistem yang tepat dengan prediksi angin yang berada di wilayah tersebut, berdasarkan kestabilannya.

Strategi penggunaan data lanjut yang dapat diterapkan adalah dengan menggunakan data time series yang memiliki jarak antar data yang lebih kecil dibanding 10 menit, karena semakin kecil jarak data maka prediksi akan lebih mendekati ke dunia nyata. Jika prediksi yang akan dilakukan memiliki scope yang jauh seperti bulanan atau bahkan tahunan, maka data yang dimiliki lebih baik mencangkup semua bulan pada tahun tersebut atau bahkan dari tahun-tahun sebelumnya juga.

\section{UCAPAN TERIMAKASIH}

Kami mengucapkan terima kasih kepada dosen pembimbing yang telah membimbing dan memberikan informasi-informasi penting dalam pemahaman konsep machine learning dan juga kami ucapkan terima kasih kepada temanteman yang telah membantu dengan pengalamannya untuk membagi ilmunya mengenai pembuatan dan pemilihan data yang lebih baik dalam pengimplementasian machine learning.

\section{DAFTAR PUSTAKA}

[1]. Pope, K., Dincer, I., \& Naterer, G. (2010). Energy and exergy efficiency comparison of horizontal and vertical axis wind turbines. Renewable Energy, 35(9), 21022113. doi: 10.1016/j.renene.2010.02.013

[2]. Alat Pengukur Kecepatan Angin. (n.d.). Retrieved from http://www.alatuji.com/m/article/detail/682/alatpengukur-kecepatan-angin

[3]. Budiartie, G. (2018, July 2). 7 Fakta Kebun Angin Pertama RI di Sidrap. Retrieved from https://www.cnbcindonesia.com/news/201807021314 31-4-21421/7-fakta-kebun-angin-pertama-ri-di-sidrap
[4]. Djumena, E. (2018, January 16). Melihat PLTB Sidrap, Pembangkit Tenaga Angin Pertama di Indonesia. Retrieved from https://ekonomi.kompas.com/read/2018/01/16/090100 826/melihat-pltb-sidrap-pembangkit-tenaga-anginpertama-di-indonesia?page $=$ all

[5]. Grinshpan, A., \& Campbell, S. (2016). Maximum Efficiency of a Wind Turbine. Maximum Efficiency of a Wind Turbine, 6. Retrieved from https://scholarcommons.usf.edu/cgi/viewcontent.cgi?a rticle $=4865 \&$ context $=$ ujmm

[6]. Helmenstine, A. M. (2020, February 4). Know the Density of Air at STP. Retrieved from https://www.thoughtco.com/density-of-air-at-stp607546

[7]. Ilmugeografi, R. (2016, September 14). Proses Terjadinya Angin dan Jenis-jenis Angin. Retrieved from https://ilmugeografi.com/fenomena-alam/prosesterjadinya-angin

[8]. 'Kincir-kincir angin raksasa' PLTB Sidrap: Mengejar ketinggalan dalam energi terbarukan. (2018, July 3). Retrieved from https://www.bbc.com/indonesia/trensosial-44679456

[9]. Papiewski, J. (2017, November 21). Horizontal Vs. Vertical Wind Turbines. Retrieved from https://education.seattlepi.com/horizontal-vs-verticalwind-turbines-3500.html

[10].Prijono, B., Prijono, B., Diterbitkan, Prijono, B., Prijono, B., \& Prijono, B. (2018, April 12). Pengenalan Long Short Term Memory (LSTM) dan Gated Recurrent Unit (GRU) - RNN Bagian 2. Retrieved from https://indoml.com/2018/04/13/pengenalan-longshort-term-memory-lstm-dan-gated-recurrent-unitgru-rnn-bagian-2/

[11].Putra, Y. M. P. (2014, June 3). Cadangan Energi Fosil Indonesia Diperkirakan Habis 2025. Retrieved from https://www.republika.co.id/berita/ekonomi/makro/14/ 06/03/n6lis0-cadangan-energi-fosil-indonesiadiperkirakan-habis-2025

[12].Studinews. (2020, April 9). Pengertian Angin, Sifat, Proses dan Kecepatannya. Retrieved from https://www.studinews.co.id/pengertian-angin/

[13].Understanding LSTM Networks. (n.d.). Retrieved from http://colah.github.io/posts/2015-08-UnderstandingLSTMs/

[14].Wind Power Calculator. (n.d.). Retrieved from https://rechneronline.de/wind-power/

[15].greener4life. (2019). Wind Power Calculators, greener4life. Retrieved from: https://greener4life.com/Wind-Energy-Calculator. 
[16].Dmanhuri, A. R., Priyadi, A., \& Purnomo, M. H. (2014). Prediksi Kecepatan Angin Jangka Pendek Menggunakan Metode Fuzzy Linear Regression Untuk Mendapatkan Masukan Pada Kontroler Turbin Angin. JURNAL TEKNIK POMITS, 1(2), 1-6. Retrieved from http://digilib.its.ac.id/public/ITS-paper-344252210100704-paper.pdf

[17].Listrik Tak Stabil, PLTB Sadrap Bakal Jadi Proyek Mangkrak. (2018, July 11). Retrieved from https://www.indopremier.com/ipotnews/newsDetail.p hp?jdl=Listrik_Tak_Stabil_PLTB_Sadrap_Bakal_Ja di_Proyek_Mangkrak\&news_id=92633\&group_news $=$ IPOTNEWS\&news_date $=\&$ taging_subtype $=$ ENER GI\&name $=\&$ search=y_general \&q=listrik,PLN,PLTB, \&halaman $=1$

\section{LAMPIRAN}

File lampiran dapat diakses pada link dibawah ini: https://drive.google.com/open?id=1MOiPvzLxe3RgLeWjIuVNl ig-2xekmIXb 